\title{
REHABILITÁCIÓ A GYAKORLATBAN - EGYÉNI FEJLESZTÉSI TERV
}

Szerző:

Csányi Mariann
Lektorok:

Varga Imre

Szegedi Tudományegyetem

Mező Katalin

Debreceni Egyetem

Schéder Veronika

Debreceni Egyetem

Mező Ferenc

Debreceni Egyetem
Szerző e-mail címe: meryenn17@gmail.com

Csányi Mariann (2015): Rehabilitáció a gyakorlatban - Egyéni fejlesztési terv, Különleges Bánásmód, I. évf. 2015/4. szám, 77-100. DOI 10.18458/KB.2015.4.77

\begin{abstract}
Absztrakt
Hogyan alkothatunk egyéni fejlesztési tervet, óratervet és fejlödési lapot? E módszertani tanulmány minta dokumentumokat mutat be és javaslatokat ad az általános ismeretek, a figyelem, a szókincs, a nyelvi rendezés, a mozgás és ritmus, a számolás és mérés, az olvasás és írás, a térbeli-, síkbeli-, és időbeli tájékozódás, a testséma, a beszéd, az analitikus és szintetikus gondolkodás, a pszichoszociális rehabilitáció, és a tanulási technikák fejlesztésére.
\end{abstract}

Kulcsszavak: rehabilitáció, habilitáció, egyéni fejlesztés, fejlesztési terv

Diszciplina: Gyógypedagógia

\begin{abstract}
REHABILITATION IN PRACTICE — INDIVIDUAL DEVELOPMENTAL PLAN MODEL

How can we create individual a development plan, a lesson plan and a development board? This methodological study shows the sample documents, and gives recommendations about development of general knowledge, attention, vocabulary, linguistic layout, movement and rhythm, counting and measurement, reading and writing, spatial, planar and time orientation, body schema, speech, analytic and synthetic thinking, psychosocial rehabilitation and learning technics.
\end{abstract}

Keywords: rehabilitation, habilitation, individual development, development plan

Discipline: special education 
KÜLÖNLEGES BÁNÁSMÓD, I. ÉVF. 2015/4.

„Sokszor kérdezik tőlem: Nick, boldog lennél, ha lennének kezeid és lábaid? Én azt felelem nekik: - Nem hiszem, hogy a boldogság a végtagokban lenne. Ha így lenne mindenki, akinek vannak kezei és lábai boldog lenne... A boldogság forrása benned van... Abban, hogy ki vagy... És nem abban mit tudsz megtenni és mit nem...(...) Van pár dolog az életben, amit se irányítani, se megváltoztatni nem tudsz, élned kell vele. Miénk a döntés, vagy feladjuk, vagy folytatjuk tovább.(...) Érdekes dolog az élet! Egyfajta utazás.”

(Nick Vujicic)

Sajátos módon az egyéni fejlesztés egyaránt kulcsfontosságú a sérült és/vagy tehetséges gyermekek mindennapjaiban. Az egyéni fejlesztés a szociális (szociokulturális) környezetből, a kompetenciák (ismeretek, jártasságok, készségek, képességek) fejlettségéből/fejletlenségéből és az iskola világához való viszonyulásokból (attitüdök) adódó hátrányok ellensúlyozását, mérséklését és/vagy az említett tényezőkből adódó előnyök felhasználását célzó tervszerü, tudatos nevelö-oktató tevékenység. Lényeges kiemelni, hogy a fejlesztő munkát a már meglévő készségekre, képességekre építve, a gyermek önbizalmának folyamatos pozitív megerősítése mellett lehet eredményesen végezni.

Az egyéni fejlesztési tervet annak érdekében készítjük el, hogy a fejlesztés menete személyre szabottan történjen és a tanuló fejlődése szempontjából kulcsfontosságú területekre nagyobb hangsúly helyeződjön az adott időszakban (például a tanév során). Ez a pont a tehetséges és a sérült gyermekeknél egyformán fontos.

A fejlesztési terv konkrét célokat, illetve a célokhoz segítő lépéseket (mintát) fogalmaz meg, és kiemelt szerepe van benne azoknak a területeknek, amelyek a tanuló érdeklődéséhez szorosan kapcsolódnak. Fontos a készségek és a tudásszint felmérése az egyéni haladási ütem megtervezésében. A fejlesztési tervet háromhavonta felül kell vizsgálni, és az abban foglaltak értékelését, tapasztalatait figyelembe kell venni a következő időszak, illetve a következő tanév megtervezésénél. Az egyéni fejlesztési terv hozzáférhető a tanuló számára, illetve a vonatkozó tartalmak hozzáférhetők az adott kérdésben érintettek számára.

Az egyéni fejlesztés tervét szervesen egészíti ki egyrészt a gyermek egyéni fejlődési lapja, másrészt a fejlesztés óraterveinek tömege. A következőkben a rehabilitáció megtervezéséhez szükséges egyéni fejlesztési terv, illetve egyéni fejlődési lap, valamint (re)habilitációs óraterv iratmintáit mutatjuk be. Noha az itt közölt iratminták példák, s intézményenként, pedagógusokként ezektől igen eltérő formátumokkal is találkozhatunk a gyakorlatban, azonban e dokumentumok általános tartalmi struktúrája - tapasztalat szerint - kevésbé változatos.

\section{Egyéni fejlesztési terv}

Az 1. ábra az egyéni fejlesztési terv egy lehetséges formátumára mutat be példát. E sablon három főbb részre osztható. Az első részben kerül összefoglalásra a gyermek neve, köznevelési intézménye/osztálya, a fejlesztési ciklus és a hónap meghatározása, a fejlesztési időszak (például: tanév) pontosítása, és az egyéni fejlesztési terv kidolgozójának neve.

A második tartalmi egység körvonalazza:

- az egyéni fejlesztési terv alapját képező kiinduló állapotot és a diagnosztikus mérések eredményeit (például a szakértői véleményben elöírt fejlesztési területeket). Néhány gyakori fejlesztési terület például: 
1. Személyiség rendezése, általános ismeretek fejlesztése,

2. Észlelés, figyelem, emlékezet fejlesztése,

3. Szókincs fejlesztése,

4. Nyelvi rendezés,

5. Mozgás és ritmus korrekciója,

6. Számolás-mérés,

7. Olvasás-írás,

8. Térbeli tájékozódás fejlesztése,

9. Síkbeli tájékozódás fejlesztése,

10. Időbeli tájékozódás fejlesztése,

1. ábra: Egyéni fejlesztési terv iratminta (forrás: a Szerző)

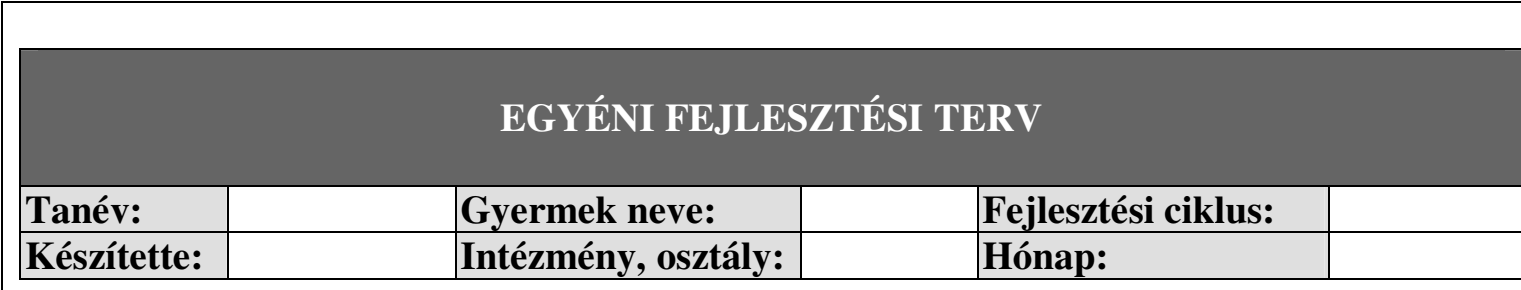

\begin{tabular}{|c|c|c|}
\hline $\begin{array}{c}\text { Kiinduló állapot és } \\
\text { diagnosztikus mérése, } \\
\text { célállapot meghatározása }\end{array}$ & $\begin{array}{c}\text { Fejlesztő tevékenység } \\
\text { módszere, eszköze }\end{array}$ & Konzultáció, tapasztalatok \\
\hline & & \\
\hline
\end{tabular}

\begin{tabular}{|c|c|c|}
\hline $\begin{array}{l}\text { Fejlesztésre szoruló részképességek, fejlesztési } \\
\text { területek, fejlesztési tevékenység, módszere, eszközök }\end{array}$ & $\begin{array}{l}\text { Fejlesztés } \\
\text { eredménye* }\end{array}$ & $\begin{array}{l}\text { Megjegyzés, } \\
\text { tapasztalat*** }\end{array}$ \\
\hline & $\begin{array}{l}\text { Nem javult. } \\
\text { Részben } \\
\text { javult. } \\
\text { Keveset } \\
\text { javult. } \\
\text { Lényegesen } \\
\text { javult. }\end{array}$ & \\
\hline
\end{tabular}

*a megfelelő eredmény aláhúzandó

**folyamatosan írható 
11. Testséma fejlesztése,

12. Beszédfejlesztés,

13. Gondolkodás (analízis-szintézis) fejlesztése,

14. Pszichoszociális rehabilitáció fejlesztése,

15. Egyénre szabott tanulási technika elsajátítása.

De itt rögzíthetők a saját felmérések és az előző időszak egyéni fejlesztési tervének záró eredményei is. A fejlesztés hatására elérendő célállapotot is ebben a részben írhatjuk körül.

- a fejlesztő tevékenység általános módszereit (a fokozatosság elvét betartva, érdeklődés felkeltés, szemléltetés, bemutatás, tevékenykedtetés, egyéniesítés, értékelés módszereire fókuszálva), eszközeit. Ez utóbbiak közt például feltüntethetők: feladatlapok; betü-, szó-, mondatkártyák; betüs dobókocka olvasó játékok; puzzle-k; formaegyeztető és egyéb képességfejlesztőnek tekinthető játékok; lottó-játékok, dominók, játéktárgyak; labda; babzsák; mozgásfejlesztő eszközök; képeskönyvek; applikációs képek; saját készítésü feladatlapok; képversek; interaktív tábla.

- konzultációkat, tapasztalatokat. A konzultációk olyan témaköröket ölelhetnek fel például, mint: szülői értekezlet keretében a gyermek otthoni tanulásának megbeszélése; konzultáció a fejlesztő foglalkozás feladatairól, céljairól, szükséges felszerelésről; tanácsadás a gyermek speciális problémáinak családi kezelésével kapcsolatban; az első félévre kitüzött célok tisztázása; órarend egyeztetés az osztályfőnökkel; óralátogatás tapasztalatainak megvitatása; hospitálást követően (gyógy)pedagógiai tanácsadás tanárnak/szülőnek; tanmenetek megismerése és fejlesztési tervbe történő beépítése.

Az egyéni fejlesztési terv harmadik tartalmi egysége már egészen konkrétan részletezi a fejlesztésre szoruló területeket (például részképességeket), a konkrét tevékenységeket és felhasználható eszközöket, a fejlesztés eredményét (legalább a „nem javult”, „részben javult”, „keveset javult”, „lényegesen javult” stb. megjegyzések szintjén, de akár számszerüen, diagnosztikai mérések alapján is), illetve a fejlesztők megjegyzéseit, tapasztalatait (ezek a fejlesztés során vagy azt követően is írhatók). Ennek a résznek a legnagyobb kihívást jelentő feladata talán a fejlesztési területekhez rendelhető tevékenységek meghatározása lehet. E kihívás leküzdésében segíthet az alábbi (teljesség igénye nélküli) összeállítás, amiből 3 hónapra (tekintve, hogy a fejlesztési terv felülvizsgálatát háromhavonta végezzük) kiválogathatjuk a gyermek számára szükséges fejlesztési tevékenységeket:

\section{Személyiség rendezését, általános ismeretek fejlesztését célzó tevékenységek lehetnek:}

-Egy óra, egy napszak, egy nap, egy hét...stb., ritmusának megtervezése először közösen, majd önállóan. Például tervezzük meg közösen, mit csináljunk a következő egy órában. Tervezzük meg a holnapi napot! Tervezzünk napirendet! Napló írása, rajzolása.

- Az időrend betartása, pontosságra nevelés: tevékenységek időbeni behatárolása, kezdő és végpontok meghatározása.

- Közvetlen környezet rendjének megteremtése, a rend fenntartása. A gyermek határozza meg a számára legfontosabb dolgok helyét!

- Az érdeklődés reális mederbe terelése - például megkezdett tevékenység befejezésre törekvés állandó önmegfigyeléssel, eredményekről beszámolók készítésével.

- Tevékenységét folyamatosan figyelemmel kísérjük, írásbeli terveket és beszámolókat kérünk. 
- Véleményalkotás, vélemények meghallgatására és elfogadására való képesség kialakítása. Például az órák zárásaként önértékelés és egymás értékelése, a vélemények meghallgatása, érvelés, elfogadás.

- Saját személyére, szükebb környezetére vonatkozóan: születési dátum, szülők, nagyszülők neve, testvérek, lakcím, telefonszám, szülők foglalkozása, iskolai végzettség, keresztnév, vezetéknév fogalma, hobbi.

- Tágabb környezetére vonatkozóan: iskola neve, címe, vele foglalkozó pedagógusok neve, tantárgyak, szakkörök, rokonság, barátok.

- Önismereti játékokkal, mondat kiegészítésekkel, igaz-hamis állítások gyüjtésével, eldöntésével, 3-4 kulcsszó alapján nevek, fogalmak kitalálása.

2. Észlelés, figyelem, emlékezet fejlesztéséhez javasolható tevékenységek többek között:

A vizuális észlelés, figyelem, differenciálás fejlesztése esetében:

• „Mi változott?” és „Keresd a párját!” játékok játéktárgyakkal, memóriakártyákkal.

• Kakukktojás játékok („Melyik nem illik a sorba?”, „Keresd az egyformákat!”).

- Tárgyak (kártyák, kavicsok, pénzérmék) megfigyeltetése, azonosak csoportosítása.

- Pontok összekötése formamásolással.

- Labirintus játék: térben, papíron, mágnessel.

- Tréfás képek. Nagy képen kis részlet megtalálása. Képek átmásolása rajzolással, pálcikával, logikai készlet elemeivel. Felvillantott képek, információk megfigyelése (látótér növelése). Lényeges információ kiemelése képekből. Figyelemmegosztás fejlesztése több egyidejű információ megadásával.

-Számtáblán, számsorozatokban megadott számok, számpárok keresése változatos számformák alkalmazásával.

- Formák elkülönítése (emlékezetből meghatározott szempont szerint dolgok felsorolása az asztalról, polcról, teremböl).

- Azonosságok, különbözőségek felismerése („Keress ugyanolyat, mint az első!”, „Figyeld meg két ábrát - egyforma vagy nem egyforma?”, „Színezd az egyformát egyforma színüre!”, ,Kösd össze/jelöld az ugyanolyat!”).

-Vizuális alak- és háttértagolás (például formák, betük, szavak, számok, képek kiegészítése egésszé, betüelemekből betük felismerése, betüsorokból kis-/nagybetük felismerése, betütáblákból szavak keresése. Tárgyak tulajdonságai alapján halmazépítés. Rendezés. Halmazok összehasonlítása ).

- Alak- és formaállandóság: betűk, számok, ábrák felismerése elforgatva egymásra rajzolva, változó helyzetekben. Rész-egész viszonyok érzékelése (kép, rajz kiegészítése, mozaik játékok, puzzle ). Reprodukciós gyakorlatok térben, síkban.

- Alak-háttér megkülönböztetése („Mi bújt el?”). Adott betű, szótag, szó kikeresése mondatból, szövegböl. Betütáblán értelmes szavak keresése (megadott szempontok szerint). Szópárok összehasonlítása. Kép - helyes szóképegyeztetés. Lépegetős figyelemfejlesztés (betüről betüre; olvasás- és írásfejlesztő feladatok ).

- Mennyiségállandóság felismerése. (Minimat készlet, színes pálcikák, színes rudak készlete, logikai készlet, Figurix, Differix segítségével). Alakkonstancia, alak- és formaállandóság (számok, ábrák felismerése elforgatva, egymásra rajzolva, változó helyzetekben). 
- Játék a logikai készlet elemeivel: sorok készítése különböző szabály alapján, formamásolás minta alapján. Tulajdonságkártyák alapján adott elem kiválasztása. „Logico Piccolo: Koncetrációs gyakorlatok".

- Figyelemmegosztás fejlesztése több egyidejü információ megadásával. Betütáblán megadott betük, szavak keresése.

A vizuális emlékezet fejlesztése esetében:

- Környezetünk tárgyainak felidézése.

- Memória játékok: „Mi változott meg?”.

• Gyorsasági képkereső („Mit takartam le?”, „Mit tüntettem el?”, „Mit cseréletem ki?”, „Mi változott meg?”).

- Játéktárgyak, képek kirakása emlékezetből.

- Gyöngyfüzés megadott minta alapján.

- Rajzemlékezet, képemlékezet, formaemlékezet. Formamásolás négyzethálóba.

- Szavak memorizálása, szótagok memorizálása szókártyákról, majd leírása.

- Számok memorizálása számkártyákról, majd leírása.

Vizuális szerialitás fejlesztése esetén:

- Tárgyak, képek sorozatának megjegyzése fokozatosan növekvő elemszámmal. Például „A polcon sorban a következő tárgyak voltak...”.

- Vizuális ritmus követése, utánzása, folytatása tárgyakkal, képekkel, vizuális szimbólumokkal, betüelemekkel, betükkel: „Rakd ki sorrendben!”, „Rajzold le ugyanolyan sorrendben!" jellegü feladatok.

- „Egyforma - nem egyforma” játék értelmes szavakkal (például: „gyönyörü györönyü”) és értelmetlen betüsorokkal (például: „banf - bafn”).

Akusztikus/verbális észlelés, figyelem, differenciálás fejlesztését szolgáló tevékenységek:

- Hangok, zörejek, hangszerek hangjának felismerése (,Minek a hangját hallottad?”).

- Jelentés nélküli szöveg olvasása (logatomok olvasása).

- Hiányos szövegek kiegészítése („Milyen betüt felejtettek ki a szóból?”).

- Azonos szótagok, szavak keresése adott szövegben („Név-út” játék).

- Szegmentálás kialakítása: mondatokra, szavakra, szótagokra, hangokra bontás (például: „Mit mondtam robotnyelven?” játék).

Akusztikus/verbális emlékezet fejlesztésének tevékenységei lehetnek például:

- Hangok önálló ejtése, pontos visszamondása.

- Szavak visszamondása.

- Logatomok visszamondása.

Akusztikus/verbális szerialitás fejlesztésének tevékenységei lehetnek többek között:

- Ritmusképletek visszamondása.

- Hangsorozatok visszamondása.

- Szósorozatok visszamondása.

- Mondatismétlések. 
3. Szókincs fejlesztését segítő tevékenységek lehetnek:

- Képválasztás alapján (állatok, gyümölcsök, zöldségek, ruhák, játékok, szerszámok, jármüvek, bútorok, virágok, foglalkozások, hangszerek, madarak, ételek, italok, háztartási gépek, evőeszközök, ünnepek, épületek stb.) főfogalom alá helyezés.

- Képi alátámasztás nélkül (kakukktojás: „Hallgasd meg a szavakat! Melyik nem illik a többi közé? Mit jelent? Válaszd ki a megfelelő szómagyarázatot!”; okos papagáj: „Akkor ismételd meg a szót, ha annak van értelme!”; szóban szó keresése: „Hány szó található ebben a hosszú szóban: sátortábor?” jellegü játékok).

- Hosszú és rövid értelmes szavak gyüjtése vegyesen.

- Föfogalom alá helyezés képekkel, képsorozatokkal, képválogatással, mozgásos játékokkal, analógiás mondatokkal.

- Ellentétpárok gyüjtése. Szinonimák gyüjtése. Szóasszociáció. Rokon értelmü szavak.

- Szóképzés. Szókígyó.

- Szóalkotás (például összetett szavak alkotása ), szólánc összetett szavakkal.

- Oda-vissza értelmes szavak (például: „,vas - sav”, „tál - lát”).

- Hasonlóan hangzó szavak (rímek találása képi alátámasztással, képi alátámasztás nélkül).

- Mondatbővítmények, önálló mondatbővítés szavakkal, tagmondattal, hiányos mondat pótlása 1-1 szóval.

- Idegen szavak, ritkán használt, régies kifejezések értelmezése, magyarázata.

- Szógyüjtés adott témához.

- Mese/történet mondása.

- Képleírás.

4. Nyelvi rendezéshez választható feladatok:

- Szógyüjtés (fönevek, igék, melléknevek).

- Szinonimák és ellentétpárok keresése.

- Mondatbefejezések („Fejezd be a mondatot!”; „Bővítsd a mondatot!” - kérdőszónak megfelelően, önállóan. Piramis mondatok készítése).

- Grammatikai rendszer kiépítése. Ragok beépítése a spontán beszédbe. Összetett mondatok alkotása. Mondatbefejezések.

- Hiányzó 3. vagy 4. kép kitalálása, megfogalmazása, lerajzolása.

- Szöveg nélküli képregényhez szöveg kitalálása.

- Nyelvtani hibák keresése („Keresd a hibát! Ismételd el hibátlanul!”).

- Képekről mondatalkotás. Képolvasás.

- Képek segítségével történetalkotás.

•Történet megfogalmazása különféle „müfajokban” („Legyen a mese vége vidám!” vagy éppen: szomorú, meghökkentő stb.).

•Eseményképröl történet összeállítása.

- Egy nap/hétvége történéseinek elmondása.

- Szabadon választott téma kifejtése. 
KÜLÖNLEGES BÁNÁSMÓD, I. ÉVF. 2015/4.

- Beszélgetés szabályainak betartása, illemszabályok megbeszélése, értelmezése, betartása.

5. Mozgás és ritmus korrekciója érdekében alkalmazható tevékenységek lehetnek:

- Helyváltoztató mozgások indítása, lassítása, leállítása („Lassított felvétel” játék, Szobor-játék, Érintés szobrok).

-Zenés mozgásgyakorlatok (például lassú, egyenletes lépés a szobában, zene ritmusára, egymás érintése nélkül, számolással elősegítve...).

- Ritmusos mozgásgyakorlatok (tanult versek ritmizálása, ritmusos kopogása ).

- Alapmozgások koordinációjának javítása.

- Testtudat kialakítása.

- Vesztibuláris rendszer fejlesztése.

- A két testfél mozgásának összerendezése.

- Egyes érzékelési területek összekapcsolására irányuló gyakorlatok.

- Finommozgás fejlesztése.

- Téri tájékozódás fejlesztése.

- Nagymozgások fejlesztése: kúszás, mászás, gurulás, járás, ugrás, labdadobás és -kapás, célbadobás, lufizás állatok mozgásának utánzása, különböző statikus helyzetek és tartások felvétele utánzás alapján. Székről leugrás, lábnyomokon lépkedés, dobbantás lábbal, ritmustapsolás, karlengetés.

- Finommozgások fejlesztése: fogás-elengedés, két ujjas fogás, integetés kézfejjel, csukló forgatása, ujjak nyitása, zárása felfelé és lefelé tartott tenyérrel. Labda dobálgatása felfelé tartott tenyérrel, asztalra fektetett tenyérrel. Ujjak emelgetése felváltva, egyenként, hüvelykujjal ujjak összeérintése, „szemüveg formálása”, ujjak sétáltatása asztalon. Labda nyomkodása tenyérrel, tenyérbe illő labda megfogása, szorítása, elengedése, labda gurítása asztalon csuklóból, majd ujjakkal, labda eldobása, elkapása két kézzel levegőben. Korong pöckölése kapuba. Golyó, pálcika, kocka kirakása minta alapján. Egér használata számítógépen. Füzés, ki-begombolás, lábujjhegyen állás/járás, mimika. Gyurmázás, tépés, csipegetés, ujjgyakorlatok mondókákkal, konstrukciós játékokkal való manipulálás, puzzle játékok összerakása, sorozatok építése színes rudakból.

6. Számolás-mérés fejlesztésekor gyakorolható tevékenységek például:

Számfogalom, mennyiségfogalom kialakítása, mennyiségállandóság, globális mennyiség felismerésének fejlesztése:

- Természetes számfogalom (pozitív egész számok) kialakítása: tárgyakkal, ujjakon. Ujjkép-tárgy egyeztetése, ujjkép-tárgy-korongkép összekapcsolása - a gyerek fejlettségi szintjéhez viszonyítva.

- Tárgyak, képek megszámlálása ujjakon, mennyiséghez számok társítása (dominó, korongok). Azonos mennyiségek kirakása azonos, különböző elemekből, halmazalkotás meghatározott elemszámmal, elemek átrendezése halmazokon belül. Különböző elemü csoportok alkotása hozzáadással és elvétellel azonos, különböző tárgyakkal.

- Utasításra megadott számú elemek kirakása, dominó kiválasztása, megfelelő számú ujj mutatása. 
- Mennyiségek összehasonlítása, különbség, egyenlőség megfogalmazása, mennyiség bontása, szabályszerüség megfigyeltetése, megfigyelése, számok egymásutánja, számsor, számsorrend, számszomszédok növekvő számkörben.

Számnevek, számjegyek differenciálása:

- A hármas asszociáció kiépítése. Számfogalom megerősítése akusztikus, taktilis, vizuális úton („Hányat tapsoltam? Hányat tettem a kezedbe?”).

- Számok felismerése tárgyakon, képeken különböző térbeli elhelyezésekben.

- Számképek-számjegyek memorizálása („Hányas számú autó győzött a versenyben? Milyen szám volt a pólóra írva?").

- Számjegyek írása, másolása diktálás után.

- Számjegyek felismerése tapintás útján.

- Számegyenes alkotása.

- Számegyenesen való tájékozódás.

- Hiányos számegyenesen a számjegyek pótlása. Számegyenes használata.

- Helyi érték meghatározása. Számok írása helyi érték meghatározása alapján.

-Számolás pénzzel.

Szövegértés fejlesztése:

- Szöveges feladatok értelmezése rajzzal, lejegyzése számokkal. Rajzokról szöveges feladatok kitalálása. Tárgyakkal manipulálva történetbe ágyazott matematikai feladatok értelmezése, visszamondása. Történetböl számok kinyerése. Matematika nyelvéről fordítás. Matematikai nyelvre fordítás.

- Szöveges feladatok szövegének megismétlése, értelmezése: összesen maradt fogalmának müvelethez kapcsolása.

- Lényegkiemelés: a megoldás szempontjából lényeges, illetve lényegtelen elemek kiválasztása.

- Adatok kigyüjtése, értelmezése a megoldás szempontjából.

- Megoldási terv készítése, megfelelő mủvelet megválasztása.

Matematikai müveletvégzés fejlesztése:

- Halmazalkotás, pótlás, bontás, összeadás, kivonás, szorzás, osztás, müveletek inverzei, szöveges feladatok, vegyes feladatok.

- Igazodás a gyermek egyéni képességeihez, haladási tempójához, eddig megszerzett tudásához közelítve az osztályfoknak megfelelő szinthez.

- Elemek azonos tulajdonságok alapján rendezése (tárgyak, képek, fogalmak, számok).

- Halmazok alkotása megnevezés után. Tulajdonságok transzformációja. Felsorolással megadott halmazok folytatása. Halmazok létrehozása minta alapján. Halmazok létrehozása elemszám megváltoztatásával. Üres halmaz kialakítása. Mennyiségek leképezése. Tanult számkörben mennyiségek bontása, pótlása szemléltetéssel (rajz, kéz ujjai, korongok, pálcikák).

- Összeadás és kivonás, mint matematikai müvelet értelmezése cselekedtetéssel, tárgyakkal, képekkel, rajzzal, majd elvontabb formában a stabil számfogalom kialakulása után fejben való számolással. 
- Számegyenes használata számszomszédok esetében vagy összeadás és kivonás végzésének megkönnyítésére.

-Százas tábla használata a müveletvégzés segítésére, az analógiás gondolkodás megerösítésére.

-5-ös, 10-es számkör majd 10-es, 20-as átlépés, helyi értékként továbblépve és megtanítva az egyes helyi értékek átlépését.

- Analógiák használata az egyes számkörök átlépésekor, számlálás automatizálása tízesével, százasával való számoláskor kerek tízesek majd teljes 2-4-jegyü számok esetében.

- Különböző beosztású számegyeneseken ugyanannak a számnak a bejelölése.

- Becslés, kerekítés gyakorlása különböző számkörökben.

7. Olvasás - írás fejlesztéséhez kapcsolódó tevékenységek például:

Betütanítást szolgáló feladatok:

- A hármas asszociáció kiépítése (beszédhang-beszédmozgás-betűalak).

- A betü optikus képének, fonetikai jellegzetességeinek megbeszélése.

- Betütanítás sorrendje (egyéniesítve!) a homogén gátlás figyelembe vételével.

- Optikus és akusztikus azonosság, különbözőség megfogalmazása, tudatosítása betüpáronként.

- Betük, szótagok, szósorok olvasása szótípusonként.

- Mondat, történet olvasása.

- Gyakorlás olvasójátékokkal: dominó, lottó, memória.

- Betühiány szavakban, mondatokban.

- Betüpótlás: rövid-hosszú, zöngés, zöngétlen, j-ly.

- Fölösleges betü keresése szavakban.

- Betü-, szótag-, szó-, mondat-, történet analízis/szintézis.

- Szótagolás.

-Szóalkotó játék: betükockával 6-8 betü kiválasztás, értelmes szó alkotása.

- Szótagkereső: összekevert szótagokból szókirakás, nehezítés: fölösleges szótagok.

Betüfelismerés, összeolvasás fejlesztése:

- Hívóképek - betükártyák egyeztetése.

- Betüvadászat betűhalmazból/betütáblán, betürácsból, dominó/lottójátékkal, memoriterekkel.

- Betük olvasása.

-2-3 betüs szótagok olvasása.

-2-3 betüs szótagok olvasása szótagkártya-kép, szótag-szótagkártya egyeztetéssel, szótagszintézissel.

- Szavak olvasása (Olvasd! Ismételd! Értelmezd!).

Szintézist/analízist gyakoroltató feladatok az olvasás/írás során:

- Szavak olvasása szószintézissel, szó-szóképegyeztetéssel, befejezéssel, kiegészítéssel.

- Szósorok olvasása szótípusonként.

- Mondatok olvasása mondatszintézissel, kép-mondatszintézissel, mondatbefejezéssel, kiegészítésekkel. 
KÜLÖNLEGES BÁNÁSMÓD, I. ÉVF. 2015/4.

- Történet/szöveg olvasása (történetszintézissel, befejezéssel, kiegészítéssel).

- Gyakorlás olvasójátékokkal: betüs dobókocka, dominó, lottó, memoriterek.

8. Térbeli tájékozódás fejlesztését segítö tevékenységek lehetnek:

- Főbb testrészek megnevezése, törzs részei, végtagok részeinek megnevezése, érintése fentről lefelé haladva.

- Oldaliság fogalma: jobb kezem, bal kezem, jobb oldalam, bal lábam, jobb lábam, jobbbal megkülönböztetése kézen, saját testen. Differenciálás a saját testen, keresztezett iránygyakorlatok. (Bemutatkozó játékok. Játék a mozdulatokkal. „Hol dobog a szíved?". Fababa. Azonos oldali testrészek mutatása, mozgatása utasításra. Ellentétes oldali testrészek mutatása, mozgatása utasításra. Menetelés. Indián szökdelés. Kövesd a vezért! Tükörgyakorlatok. )

- Oldaliság kialakítása belső testélményből.

- Tájékozódás térben: viszonyfogalmak, test mozgatása megadott irányba, irányhármasság (Hová? Hol? Honnan?).

- Térbeli viszonyok megnevezése, névutók helyes használata.

- Sorolvasás tanítása. Sor eleje, sor vége (balról jobbra való haladás automatizálása). Alsó, felső, középső sor fogalma. Labirintus játék. Robotos játék. Játék a mozdulatokkal.

- Sorozatok tárgyakkal: sor eleje, sor vége, közepe. Sorolvasás, sorváltás. Sor, oszlop fogalma. Első, utolsó, középső oszlop fogalma. Csukott szemmel a teremben lévő tárgyaknak, személyeknek pontos helymeghatározása. „Mi van messzebb? Mi van lejjebb és feljebb?". Ábrasorból a téri helyzetben oda nem illő kiválasztása. Ábrasorból az adott mintával azonos kiválasztása. Téri tollbamondás, cselekvéses feladatok. Nyitott mondatok befejezése. Szövegkiegészítés, szövegjavítás térbeli viszonyszavakkal.

-Alsó, felső, középső sor fogalma.

- Első, utolsó, középső oszlop fogalma (Sorbaállással, játéktárgyak sorba állításával, majd tárgyképekkel folytatjuk a gyakorlást. „Ki az első a sorban?”. Gyakorlás feladatlapon).

- Tájékozódás hármas vonalközben. (Ház részeinek megnevezése, utcák elnevezése táblai rajz segítségével. Saját házikóba képecskék behelyezésével. Hány utcába fér el? Tárgyképek helyének megkeresése, tárgykép behelyezése az adott helyre. A cica a padlásra költözött, az egér a pincébe).

- Tájékozódás pontrendszerben (Cselekedtetéssel. Cukorka elhelyezése az adott pontra. Virágos kerttel, méhecskékkel gyakorlás. Feladatlapok.)

- Iránygyakorlatok (Csoszogó. „Hideg-meleg-hol van?” játék, labirintus játék).

9. Síkbeli tájékozódás fejlesztését segítö tevékenységek:

- Tájékozódás függőleges síkban (vetített képen, táblán), vízszintes síkban (padon, füzetben), fentről lefelé, balról jobbra, vonalközben.

- Manipulálás képekkel. Kép kiegészítése utasítás alapján, irányoknak megfelelően. Szomszédok meghatározása. „Nyíl mutatja az utat” rejtvények. Kérdés-felelet játékok eseményképről. Vicces rajzok (Miért nem valóságos?). 
• Formamásolás négyzethálóban, fokozatosan növekedő pontrácsban. „Labirintusok” másolása. Csoszogó. Varázsképek irányok követésével. Rajz készítése az irányok megnevezésével négyzetrácsban.

- Oszlop, sor fogalma síkban. Torpedó formákkal, számokkal. Dátumkereső. Területfoglaló négyzetrácsban.

- Tájékozódás mátrixban. Átfordítás függőleges síkből vízszintesbe (Ábrák, ábrasor kirakás, másolása tábláról füzetbe.) Logico Maximo: Tükrözés és forgatás.

10. Időbeli tájékozódás fejlesztése:

- Idő és a természet ritmusának megfigyelése, visszaemlékezés történésekre. Az idő ritmu-sa, a természet ritmusa.

•Évszakok jellemzői, eseményei, körforgása. Évszakok társas, puzzle. Hiányos képek pót-lása. Történethez évszak társítása.

- Hét napjai, eseményei. Tájékozódás egy napon belül: napszakok, napi események időtar-tama. Időpont, időköz pontosítása (mikor? mettől-meddig?), tegnap, holnap, tegnapelött, holnapután, hétköznap, hétvége fogalma. Hét napjai oda-vissza sorrendben.

- Hónapok körforgása, hónapok évszakok kapcsolata. Évszakok eseményei. Órabeállítás, időbecslés, időmérés.

- Dátumok, események időrendje, időtartama. Egyéni ünnepek, dátumok időrendje.

- Naptár (heti, havi, évszakot átfogó, éves) használata.

- Idő mértékei, ,átváltások” (negyed, fél év, fél nap fogalma). Emberi élettartam, saját életkor tudatosítása, összehasonlítása másokéval, fiatal-idős, mint viszonyfogalmak.

- Az eltelt idő érzékeltetése, történetrendezés időrendben (képek, mondatcsíkok). Hiányos mondatok kiegészítése időfogalmakkal. Időfogalmak ellentétpárjának megkeresése.

\section{Testséma kialakitása, fejlesztése során alkalmazható tevékenységek lehetnek:}

- Föbb testrészek megnevezése, saját testen, társon, bábun.

- Törzs részei, végtagok (kéz, láb), érzékszervek megmutatása, megnevezése (mire használjuk?), arc részeinek megnevezése, érintése fentről lefelé haladva (kinesztéziát is bekapcsolva az érzékelésbe). „Nehéz” testrészek megmutatása, megnevezése. Testrajz. Szétvágott emberkép összeillesztése. Hiányos emberrajzok kiegészítése. Testpontok. Simogató játék. Rendőrjáték. Szobrászjáték. Méhecskés játék. Játék a lenyomatokkal. „Ez volnék én” gyakorlókönyv. Testrész mennyiség összekapcsolása. Bal, jobb oldal megta-nítása, differenciálása.

\section{Beszédfejlesztés tevékenységei dióhéjban:}

- Beszédkedv, kontaktus felkeltése (hangutánzás, bábozás, képeskönyv nézegetés).

- Artikulációs mozgásügyesítés (ajak- és állgyakorlatok, fúvó-pattintó gyakorlatok, nyelv-gyakorlatok).

- Ciklizálás. Ciklikus- és aciklikus sorokkal (bábozással, labdagurítással, székről leugrálás-sal, gyöngyfüzéssel, firkálással, formaazonosítással).

- Hallási diszkrimináció fejlesztése. A figyelem ráirányítása a hangok sokféleségére. Szoborjáték hangjelzésre. Környezetünk hangjai felismerése magnóról.

Szókincs fejlesztése (figyelem, emlékezet, észlelés, szerialitás fejlesztésével): 
KÜLÖNLEGES BÁNÁSMÓD, I. ÉVF. 2015/4.

-Szókincsfejlesztés utánmondással. Tárgyak válogatása analógiás sorok kirakásával. Játék-polcon rendrakás. Adott tárgy megtalálása tapintás útján.

- Passzív szókincs fejlesztése. Tárgyak, képek közül a megfelelő kiválasztása. 1-2 tárgy vagy kép kiválasztása emlékezetből.

- Aktív szókincs fejlesztése. Azonos tárgyak szétválogatása. Analógiás sorok kirakása. Verbális emlékezet fejlesztés 2-3 kép visszakeresésével, majd önálló megnevezésével. 2-3 kép közül az egyik lefordítása, két kép helycseréje. Tapintásfejlesztés („Mi van a kendő alatt?").

• Magmondatok kialakítása. Egyszerü mondatalkotás. Házikóból állatkák előhúzása.

13. Gondolkodás (analízis-szintézis) fejlesztését támogató tevékenységek:

- Puzzle játékok.

- „Keresd a kisképet a nagyképen!” feladat.

- Csoportosítás különböző tulajdonságok alapján.

- Analógiák szerint csoportok alkotása.

- Rajzos sorok folytatása szabálymegadással, szabályfelismeréssel.

- Mennyiségek leképezése.

- Hozzárendelések, egyeztetések.

- Konkrét tapasztalat elvonttá alakítása és viszont.

- Összeadás, kivonás, szorzás, osztás műveletének értelmezése.

- Képröl szöveges feladat alkotása.

- Logico Piccolo: Logikai feladványok.

- Logico Maximo: Eltolás és mozgatás.

14. Pszichoszociális rehabilitációt szolgáló tevékenységek:

- szülőkkel együtt a napi teendők megbeszélése

- a túlzott féltés, aggodalmak miatti helyes értékrend kialakítása

- pszichológus segítségét elfogadtatni

- anyáról leválás elősegítése

- barátokkal, osztálytársakkal tanítási órán kívüli szabadidős tevékenységek elősegítése

- önálló tevékenységre biztatás

- A feldolgozott szöveg alapján az emberi természet átgondolása a helyes viselkedés megbeszélése.

15. Egyénre szabott tanulási technika elsajátítása:

- A gyermek személyiségét, tudását, önállóságát figyelembe véve nyújtani a megfelelő tanulástechnikai módszert.

- Feldolgozandó szöveg otthoni, az órán megbeszéltek alapján való egyedüli, kérdések alapján történő feldolgozása.

- Az IPOO-minimum program kreatív tanulási stratégiáinak gyakorlása (Mező, 2011; Mező és tsai, 2011). 
A személyiség rendezésével, a testséma és a pszichoszociális készségekkel kapcsolatos fejlesztéshez Kocsis és Rosta (2006), Márkus (1994), Szászné és Varga (2005) és Mező (2015) müveiben találhatunk praktikus segítséget.

Az olyan kognitív képességek, mint az észlelés, figyelem, emlékezet, gondolkodás, kreativitás esetében Mező és Mező (2003), Dékány (2004), Tárnok (2005), Pšenáková és Mező (2010), Mező és Mező (2013), Mező K. (2015) müvei lehetnek segítségünkre fejlesztési terveink megalkotásakor, valamint a Hangyácska logikai képességfejlesztő szoftvert aajánlom az Olvasók figyelmébe.

Nyelvi készségek, képességek, szókincs fejlesztése, nyelvi rendezés esetén javasolt szakirodalom például: Vannay (2005), Tölgyszéky (1995, 2003), Ismerd meg az ellentéteket címü szoftver. A szűkebb értelemben vett beszédfejlesztéshez pedig Balázsné és Ammerné (2003), Balogh és tsai. (1998), Besztercei (2005), Bittera és Juhász (2014), Juhász (1999) művei lehetnek iránytadók.

Az olvasás-írás fejlesztéséhez kapaszkodókat találunk például Adorján (2008), Batáné és tsai. (1997), Csabay (2013, 2014), Kárpátiné, Tasnádyné és Vajda (2003), Meixner 81994, 2013) és Tarnai (2006) müveiben, illetve olyan szoftverekben, mint: Dinamikus olvasás, Helyesírási gyakorló, Magyar helyesírás, Manó ábécé, Manó nyelvtan, Manó olvasás.

Motoros képességek fejlesztéséhez Márkus (1994); Rosta, File és Arany (2012) és Szabó (2006) írásaiban nyerhetünk ihletet.

Számolás-mérés fejlesztését szolgáló tevékenységek tervezésekor haszonnal forgathatók például az alábbi müvek: Alkonyi és Rosta (1993), Bernáthné és tsai. (1996), Büchler (1995), Csonkáné (2006), Dékány és tsai. (2002), Hajdu és tsai. (2004), Kormosné és Tokai (2006), Mesterházi (1999), Rónai és tsai. (2003), Rosta és tsai. (2012), Szabó és Szabó (2001), Tálas (2006) és Villányi (1993). De a Manó matek, Fantasztikus matekváros, matek iskola jellegü szoftverek is jó szolgálatot tehetnek.

A térbeli, síkbeli, időbeli tájékozódás fejlesztéséhez javasolt szakirodalom: Jakus (2009a,b), Nagyné (1996).

Az egyénre szabott tanulási technikák fejlesztését segítő szakirodalom például: Kulcsár (2014), Mező F. (2011), Mező és tsai. (2011) és Valett (1996).

Általában véve pedig az alábbi művekben találhatunk ötleteket fejlesztési tervünkhöz: Büchler (2011), Dobosné és Bozsik (1997), Dovala (1987), Fejér (2004), Ferlingné (2009), Hegyi (2000), Kelemen (2008), Marosits (2005), Németh és S. Pintye (2006), Németiné (2003), Papp (2004), Perlai (2014), Pethő (2003), Porkolábné (2009), Presserné (2003), Rosta (2004), Sedlak és Sindelar (2005), Simonné (1998), Szakácsné (2006, 2007), Szautner (2006), Szebenyiné (2006) és Székely (2014). Javasolt szoftverek továbbá: Aprófalva, Játszóház gyerekeknek, Manó kaland.

\section{Rehabilitációs-habilitációs óraterv}

Az óraterv már nagyon részletes, akár percekre lebontott időegységekben foglalja össze egyegy (re)habilitációs foglalkozás történéseit (2. ábra). Két főbb részre bontható. Az első részben rögzítjük a gyermek/csoport nevét, a foglalkozás helyét, a tanévet, a pedagógus nevét, az óra típusát, a főbb fejlesztendő terület(ek)et, az óra anyagát és tevékenységeit, fogalmait, a fejlesztés célját, a javasolt szakirodalmat. 
KÜLÖNLEGES BÁNÁSMÓD, I. ÉVF. 2015/4.

A második részben foglaljuk, össze, hogy mennyi időt szánunk, mire, milyen módszereket és eszközöket alkalmazunk és milyen didaktikai célokat, feladatokat szolgálunk éppen. Az 1. számú mellékletben található egy kitöltött rehabilitációs-habilitációs óraterv demonstrációképpen.

2. ábra: rehabilitációs-habilitációs óraterv sablon (forrás: a Szerző)

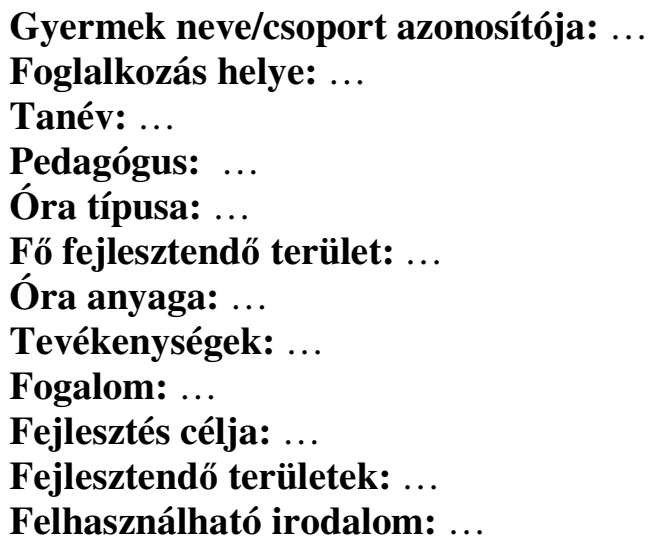

\begin{tabular}{|c|c|c|c|c|c|}
\hline Idő & Fejlesztés menete & $\begin{array}{c}\text { Fejlesztendö } \\
\text { terület }\end{array}$ & $\begin{array}{c}\text { Módszerek, } \\
\text { eszközök }\end{array}$ & $\begin{array}{c}\text { Didaktikai célok, } \\
\text { feladatok }\end{array}$ & Megj. \\
\hline & & & & & \\
\hline & & & & & \\
\hline & & & & & \\
\hline$\ldots$ & $\ldots$ & $\ldots$ & & & $\ldots$ \\
\hline
\end{tabular}

\section{Egészségügyi és pedagógiai célú habilitáció, rehabilitáció egyéni fejlődési lap}

Az egyéni fejlődési lapot foglalkozásról foglalkozásra vezetjük. Célja: a fejlesztés nyomon követhetőségének biztosítása a fejlesztésbe bevont gyermekek, szülők és szakemberek számára egyaránt (de: az egyéni fejlődési lapba történő betekintés engedélyezésének mérlegelésekor mindig szem elött kell tartani a gyermek személyiségi jogait, s biztosítani kell a személyes adatok védelmét!).

Az egyéni fejlődési lap lényegében véve két tartalmi egységből áll (3. ábra). Az első részben a foglaljuk össze a gyermekre, fejlesztési területre, pedagógusra és időszakra vonatkozó adatokat. A második egységben közöljük a foglalkozás sorszámát, időpontját, tartalmát, módszereit, eszközeit, megjegyzéseinket. Amennyiben több szakember is be van vonva ugyanannak a gyermeknek a fejlesztésébe, s egyazon fejlődési lapot vezetik, akkor célszerü, ha minden szakember önmaga tölti ki a rá vonatkozó adatokat, s aláírásával egyrészt hitelesíti azokat, másrészt felelőséget vállal a leírtakra, s az elvégzett tevékenységekre. 
KÜLÖNLEGES BÁNÁSMÓD, I. ÉVF. 2015/4.

3. ábra: egyéni fejlödési lap iratmintája (forrás: a Szerzö)

\begin{tabular}{|l|l|}
\hline \multicolumn{2}{|l|}{} \\
\hline
\end{tabular}

\begin{tabular}{|c|c|c|c|c|}
\hline Sorszám & Időpont & $\begin{array}{c}\text { A foglalkozás tartalma, } \\
\text { módszerei, eszközei }\end{array}$ & Megjegyzés & Aláírás \\
\hline & & & & \\
\hline & & $\ldots$ & $\ldots$ & \\
\hline & & $\ldots$ & $\ldots$ & \\
\hline & $\ldots$ & $\ldots$ & & \\
\hline
\end{tabular}

\section{Összefoglalás}

Az egyénre szabott, differenciált fejlesztés alapja - akár habilitációs, akár rehabilitációs, akár tehetségfejlesztői törekvések álljanak a háttérben - ideális esetben átgondolt, megtervezett pedagógiai folyamat. E tervezést olyan dokumentumok segíthetik, mint például az egyéni fejlesztési terv, az óravázlat, illetve az egyéni fejlődési lap. Míg az előző két dokumentumot a fejlesztés elött állítjuk elö, addig a fejlődési lap a fejlesztés során alakul.

Ne feledjük, hogy a pedagógiai folyamat megtervezése ugyanolyan lényegi része a szakszerü fejlesztő tevékenységnek, mint a fejlesztés célterületeit kitüző, s e célok elérését ellenőrző diagnosztika elvégzése (Mezö és tsai, 2015a,b).

\section{Irodalom}

Adorján K. (2008): Gyakorlóanyag I., II., III. Meixner mühely, Budapest.

Alkonyi M. és Rosta K. (1993): Számlálni kezdek. Számolásfejlesztő feladatlap-gyüjtemény. Ictus, Szeged.

Balázsné Fige I. és Ammerné Nagymihány E. (2003): Beszédfejlesztés és környezetismeret I. Nemzeti Tankönyvkiadó, Budapest.

Balogh Zs., Becsei Józsefné, Dancsóné Kasznár M. és Sánta M. (1998): Anyanyelvi, kommunikációs képességfejlesztés. IPSZILON Kiadó, Békéscsaba. 
Batáné M.E., Kisné B. Zs. és Koncz A. (1997 ): Értjük!? Képességorientált, hatékonyságnövelő olvasás-, írástanítás program. Szalay Könyvkiadó, Kisújszállás.

Bernáthné Nagy Á., Mátrai Józsefné és Tálas Józsefné (1996): Gyakorlólapok a készségszintü számolás fejlesztéséhez. Fejlesztő munkalapok A számok világához. Nemzeti Tankönyvkiadó, Budapest.

Besztercei E. (2005): Másképp. Logopédia Kiadó, Budapest.

Bittera Tiborné és Juhász Á. (2014): Én is tudok beszélni 1. Munkatankönyv. Nemzeti Tankönyvkiadó, Budapest.

Büchler J. (1995): A mennyiségfogalom fejlesztése játékos gyakorlatokkal. FPI, Budapest.

Büchler J. (2011): Ötlettár. Flaccus Kiadó, Budapest.

Csabay K. (2013): Lexi iskolás lesz. Nemzeti Tankönyvkiadó, Budapest.

Csabay K. (2014): Lexi. Nemzeti Tankönyvkiadó, Budapest.

Csonkáné Polgárdi V. (2006 ): Számolás 1., 2. Logopédia Kiadó, Budapest.

Dékány J. (2004): Mit gondolsz? 1. Összefüggések, 2. Analógia, 3. Összehasonlítás. Logopédia Kiadó, Budapest.

Dékány J., Cortívo E., Darvas Istvánné és Egri K. (2002): Kép és szöveggyüjtemény számolni tanuló gyerekeknek I., II. Logopédia Kiadó, Budapest.

Dobosné Bányai V. és Bozsik R. (1997): Óvodából iskolába, felkészítö füzet 5-7 éveseknek, az óvodák iskolára elökészítö csoportjai számára. Nemzeti Tankönyvkiadó, Budapest.

Dovala M. (1987): Nyitogató. Tankönyvkiadó Vállalat, Budapest.

Fejér Zs. (2004): Csoszogó - Képességfejlesztő Munkafüzet. Mozaik Kiadó, Szeged.

Fejlesztölapok I. Feladatlapok az értelmileg akadályozottak számára. Nemzeti Tankönyvkiadó,Budapest 1998.

Ferlingné Csányi E. (2009): Játsszunk együtt. Krasznár és Fiai Kkt, Budapest.

Hajdu S., Novák Lászlóné és Scherlein M. (2004): Furfangos fejtörö - Matematika 1-2. feladatgyüjtemény. Müszaki Könyvkiadó, Budapest .

Hegyi I. (2000): Fejlődési lépcsőfokok az óvodáskorban. Okker Kiadó, Budapest.

Jakus J. (2009a): Téri tájékozódás Irányok. Fimota Központ, Budapest.

Jakus J. (2009b): Téri tájékozódás Pontrácsok; Fimota Központ, Budapest.

Juhász Á. (szerk)(1999): Logopédiai vizsgálatok kézikönyve. Új Múzsa Kiadó, Budapest.

Kárpátiné, Tasnádyné és Vajda (2003): Betüről betüre Olvasásfejlesztö füzetek. Krónika Nova Kiadó, Budapest.

Kelemen L. (szerk.) (2008) : Képességmérés az óvodában. Poliforma Kft, Hajdúböszörmény.

Kocsis Lászlóné és Rosta K. (2006): Ez volnék én? Logopédia Kiadó, Budapest.

Kormosné Kovács T. és Tokai Cs. T. (2006): Én is tudok számolni! - Feladatlap-gyüjtemény 1.2. 3. Számolásgyenge, dyscalculiás gyermekek részére. Nemzeti Tankönyvkiadó, Budapest.

Kulcsár Mihályné (2014): A tanulás öröm is lehet! Neuro-Logo-Ped Kft, Bicske.

Márkus E. (1994): Képességfejlesztő eszközök a súlyosan és halmozottan sérült mozgásfogyatékos gyermekek gyógypedagógiai nevelésében. ELTE, Budapest.

Marosits Istvánné (2005): Tudod-e?; Logopédia Kiadó, Budapest.

Meixner I. (1994): Írólapok. Tanszer-Tár, Budapest.

Meixner I. (2013): Én is tudok olvasni. Nemzeti Tankönyvkiadó, Budapest.

Mező F. (2011): Tanulás: diagnosztika és fejlesztés az IPOO-modell alapján. K+F Stúdió Kft., Debrecen.

Mező F. (2015): Kreatív kapcsolatalakitási stratégiák. K+F Stúdió Kft., Debrecen. 
KÜLÖNLEGES BÁNÁSMÓD, I. ÉVF. 2015/4.

Mező Ferenc, Máth János, Abari Kálmán és Mező Katalin (2015a): Fejlesztőprogramok egymintás, kritériumorientált hatásvizsgálatának matematikai statisztikai háttere. Különleges Bánásmód, I. évf. 2015/3. szám, 69-78. DOI 10.18458/KB.2015.3.69

Mező F., Máth J., Abari K. és Mező K. (2015b): Fejlesztőprogramok önkontrollos hatásvizsgálatának matematikai statisztikai háttere. Különleges Bánásmód, I. évf. 2015/4. szám, 65-75. DOI 10.18458/KB.2015.4.65

Mező F. és Mező K. (2003): Kreatív és iskolába jár! Tehetségvadász Stúdió - Kocka Kör Tehetséggondozó Kulturális Egyesület, Debrecen.

Mező F. és Mező K. (szerk.)(2013): Képességfejlesztés - elmélet és példatár. Debreceni Egyetemi Kiadó. Debrecen.

Mező F., Mező K. és Mező L. D. (2011): Tanulógép. Tanulás módszertani javaslatok. K+F Stúdió Kft. Debrecen.

Mező K. (2015): Kreativitás és élménypedagógia. Kocka Kör, Debrecen.

Mesterházi Zs. (1999): Diszkalkuliáról pedagógusoknak. ELTE, Budapest.

Nagyné Réz I. (1996): Téri tájékozódás fejlesztő program. ELTE BGGYFK, Budapest.

Németh E. és S. Pintye M. (2006): Mozdul a szó. Logopédia Kiadó, Budapest.

Németiné Borbás A. (szerk.)(2003): Játékosan... Játékgyüjtemény a részképességek fejlesztéséhez. Eu-Synergon Kft, Vác.

Papp L. (szerk.) (2004): Képességfejlesztés, képességmérés az óvodában. Didakt Kiadó, Debrecen.

Perlai Rezsőné (2014): Az óvodáskor fejlesztőjátékai. Flaccus Kiadó, Budapest.

Pethő M. (szerk.)(2003): Játssz velem! Ec-Pec Alapítvány, Budapest.

Porkolábné Balogh K. (szerk.) (2009): Komplex prevenciós óvodai program (Kudarc nélkül az iskolában). Trefort Kiadó, Békéscsaba.

Presserné Vér K. (2003): Játékos suliváró. Dinasztia Tankönyvkiadó, Budapest.

Pšenáková, I. és Mező, F. (Szerk.)(2010): Képességfejlesztés digitális tananyaggal. Kocka Kör, Debrecen.

Rónai J., Soltészné B.I. és Velkeyné G. Zs. (2003): A számolás mérés előkészítése. Nemzeti Tankönyvkiadó, Budapest.

Rosta K. (szerk.)(2004): Taníts meg engem! Logopédia Kiadó, Budapest.

Rosta K. és Kocsis Lászlóné (2006): Ez volnék én? Logopédia Kiadó, Budapest.

Rosta K., Egri K. és File E. (2012): Színezd ki és számolj te is! Göncöl Kiadó, Budapest.

Rosta K., File E. és Arany (2012): Színezd ki és rajzolj te is! Göncöl Kiadó, Budapest.

Sedlak, F. és Sindelar, B. (2005): „De jó, már én is tudom!” ELTE BGGYFK, Budapest.

Simonné Zachár A. (1998): Iskolába készülök. Mokka, Pápa.

Szabó B. (2006): Mozdulj rá! Logopédia Kiadó, Budapest.

Szabó O. és Szabó I. (2001): Számról számra. Matematikai munkafüzet nehezen számoló gyerekeknek. VMPI, Szombathely.

Szakácsné Kupeczki É. (2006): Kukucskáló. Pannon Literatúra Kft, Kisújszállás.

Szakácsné Kupeczki É. (2007): Lánc, lánc, lánc. Szalay Könyvkiadó, Kisújszállás.

Szászné, Varga K. (2005): Segítőkészség. Ec-Pec Alapítvány, Budapest.

Szautner Jánosné Szigeti G. (2006): Nebuló 1., 2., 3., 4. Marketing Mühely Kft, Szolnok.

Szebenyiné Nagy É. (2006): Böngésző. Logopédia Kiadó, Budapest.

Székely Balázsné (2014): Részképességek I. II. Müszaki Könyvkiadó, Budapest.

Tálas Józsefné (2006): Számolás 1., 2., 3. 4. Logopédia Kiadó, Budapest.

Tarnai K. (2006): Betüsuli 1., 2. Logopédia Kiadó, Budapest. 
Tárnok G. (2005): Pontról pontra pontosan. Logopédia Kiadó, Budapest.

Tölgyszéky Papp Gyuláné (1995): Képességfejlesztő technikák és eljárások az anyanyelv tanításában; ELTE BGGYFK, Budapest.

Tölgyszéky Papp Gyuláné (szerk.)(2003): A tanulási nehézségek kezelése - Kézikönyv a habilitációs programcsomag használatához. Logopédia Kiadó, Budapest.

Valett, R. E. (1996): A tanulási zavarok terápiája. BGGYFK, Budapest.

Vannay Aladárné (2005): Szórejtő szófejtő. Logopédia Kiadó, Budapest.

Villányi Györgyné (1993): Játék a matematika? Tárogató Kiadó, Budapest.

CD ROM - Szoftver:

Aprófalva. Játékos oktatóprogam 4-8 éves gyerekeknek. Bp. Unit, 2000. 1 CD-ROM

Dinamikus olvasás. Számítógépes olvasásfejlesztő Windows környezetben. Bp. AKG, 1996. 1 floppy

Fantasztikus matekváros. Bp. Automex, 2000. 1 CD-ROM

Hangyácska és a Logikai készlet 1. Játékos oktatóprogram óvodásoknak. Baja. Profi-Media Kft., 2002. 1 CD-ROM

Helyesírási gyakorló szoftver 1440 szóval 1-4. osztályosoknak. Bp. Marconi, 1998. 1 floppy

Ismerd meg az ellentéteket. Bp. Woodstone Interactive, 2000. 1 CD-ROM

Játszóház gyerekeknek. Bp. Cyberstone, 1998. 1 CD-ROM

Magyar helyesírás. Gyakorló szoftver haladóknak, felsösöknek és nagyobbaknak. Bp. Marconi, 1998. 1 floppy

Manó ábécé. Játékos oktatóprogram 5-8 éves gyerekeknek. Baja. Profi-Media Kft., 1999. 1 CD-ROM

Manó kaland. Játékos oktatóprogram 5-9 éves gyerekeknek. Baja. Profi-Media Kft., 2002. 1 CD-ROM

Manó matek 1-4. Játékos oktatóprogram 5-12 éves gyerekeknek. Baja. Profi-Media Kft., 19982003. 4 CD-ROM

Manó nyelvtan. Játékos oktatóprogram 7-10 éves gyerekeknek. Baja. Profi-Media Kft., 2004. 1 CD-ROM

Manó olvasás. Játékos oktatóprogram 5-8 éves gyerekeknek. Baja. Profi-Media Kft., 1999. 1 CD-ROM

Manófalva. Matematika. Bp. Nemzeti Tankvk., 1997. 1 CD-ROM

Matek iskola. Számolj velünk. Matematika oktató program 5-8 éves gyerekeknek. Bp. Woodstone Interactive, 2000. 2 CD-ROM 


\section{1. melléklet}

\section{Rehabilitációs - habilitációs óratervezet}

Foglalkozás helye: EGYMI Intézmény

Tanév: 2015/2016 tanév

Pedagógus: Csányi Mariann - gyógypedagógus

Óra típusa: Gyógypedagógiai rehabilitáció - habilitáció

Fö fejlesztendő terület: Számolás - mérés fejlesztése

Óra anyaga: Számfogalom megerősítése bontással, mennyiségek. Mennyiségállandóság.

Tevékenységek: Lépések betartásával, szemléltetéssel - a számfogalom rögzítése.

Fogalom: Bontás.

Fejlesztés célja: A mennyiség, a számkép és a számjegyek összehasonlítása - számfogalom biztos használata. Fejlesztendő területek:

- Emlékezet fejlesztése

- Figyelem-koncentráció fejlesztése

- Finommotoros fejlesztés

- Matematikai gondolkodás fejlesztése

- Matematikai nyelvezet gyakorlása

- Matematikai relációk gyakorlása

- Mennyiség (ujjkép) és számkép egyeztetésének gyakorlása

- Mondatalkotás gyakorlása

- Önbizalom fejlesztése, motiválás

- Összeadás-kivonás gyakorlása tízes számkörben

- Páros és páratlan számok gyakorlása

- Szám- és mennyiségképek egyeztetése

- Számok gyakorlása 1-10-ig

- Számok sorrendiségének gyakorlása

- Számszomszédok felismerésének gyakorlása

- Szerialitás fejlesztése

\section{Felhasználható irodalom:}

- Csonkáné Polgárdi Veronika: Számolás 1.; 2. Logopédia Kiadó 2006.

- Hajdu Sándor_Novák Lászlóné-Scherlein Márta: Furfangos fejtörö - Matematika 1-2. feladatgyüjtemény. Müszaki Könyvkiadó 2004.

- Kormosné Kovács Tünde - Tokai Csilla Tünde: Én is tudok számolni! - Feladatlap-gyüjtemény 1.2. Nemzeti TK 2006.

- Rónai Judit - Soltészné B.I. - Velkeyné G. Zs.: A számolás mérés előkészítése. Nemzeti TK 2003.

- Rosta Katalin-Egri Katalin-File Edit: Színezd ki és számolj te is! Logopédia Kiadó 2012.

- Tálas Józsefné: Számolás 1., 2. Logopédia Kiadó 2006.

- Tölgyszéky Papp Gyuláné szerk.: A tanulási nehézségek kezelése - Kézikönyv a habilitációs programcsomag használatához. Logopédia Kiadó 2003.

\begin{tabular}{|c|c|c|c|c|c|}
\hline $\begin{array}{c}\text { Id } \\
\text { ô }\end{array}$ & Fejlesztés menete & $\begin{array}{c}\text { Fejlesztendő } \\
\text { terület }\end{array}$ & $\begin{array}{c}\text { Módszerek, } \\
\text { eszközök }\end{array}$ & $\begin{array}{c}\text { Didaktikai } \\
\text { célok, } \\
\text { feladatok }\end{array}$ & Megj \\
\hline \multirow[b]{2}{*}{$\begin{array}{l}1 \\
3\end{array}$} & Bevezetés: & \multirow[b]{2}{*}{$\begin{array}{c}\text { Szám - ujjkép } \\
\text { - mennyiség } \\
\text { felismerése. } \\
\text { Analízis - } \\
\text { szintézis. } \\
\text { Figyelem - } \\
\text { koncentráció } \\
\text { fejlesztése. } \\
\text { Rész - egész } \\
\text { viszony } \\
\text { értelmezése. }\end{array}$} & \multirow{2}{*}{$\begin{array}{l}\text { Cselekedtetés. } \\
\text { „LOTTÓ” tábla } \\
5 \text { korong. }\end{array}$} & \multirow[b]{2}{*}{$\begin{array}{c}\text { Szám - ujjkép - } \\
\text { mennyiség } \\
\text { egyeztetése, } \\
\text { felismerése } \\
\text { játékosan. } \\
\text { A keresés } \\
\text { lényege a játék: } \\
\text { kitűzünk egy } \\
\text { utazási célt... és } \\
\text { ha } 5 \text { találata }\end{array}$} & \\
\hline & $\begin{array}{l}\text { Most pedig LOTTÓZNI fogunk! Adok neked } 5 \\
\text { korongot, mind az ötöt el kell használni, mert } \\
\text { csak akkor nyersz, ha } 5 \text { találatod van! } \\
\text { A feladat az, hogy mondok egy számot } 1-5 \text {-ig, } \\
\text { a szelvényen } 5 \text { olyan mező van, ami a számhoz } \\
\text { kapcsolódik, keresd meg, ha megtaláltad tedd rá } \\
\text { a korongot! }\end{array}$ & & & & \\
\hline
\end{tabular}




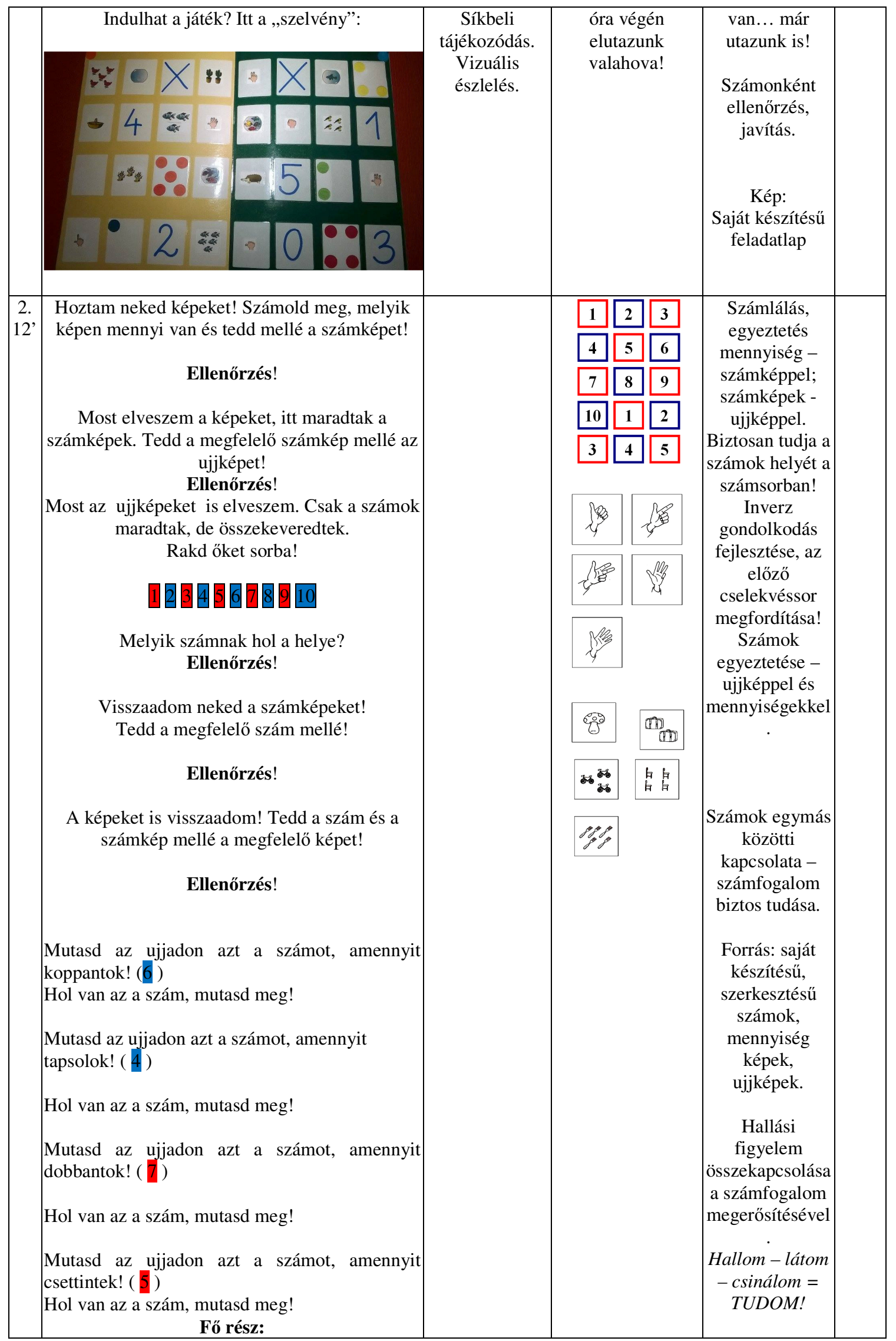




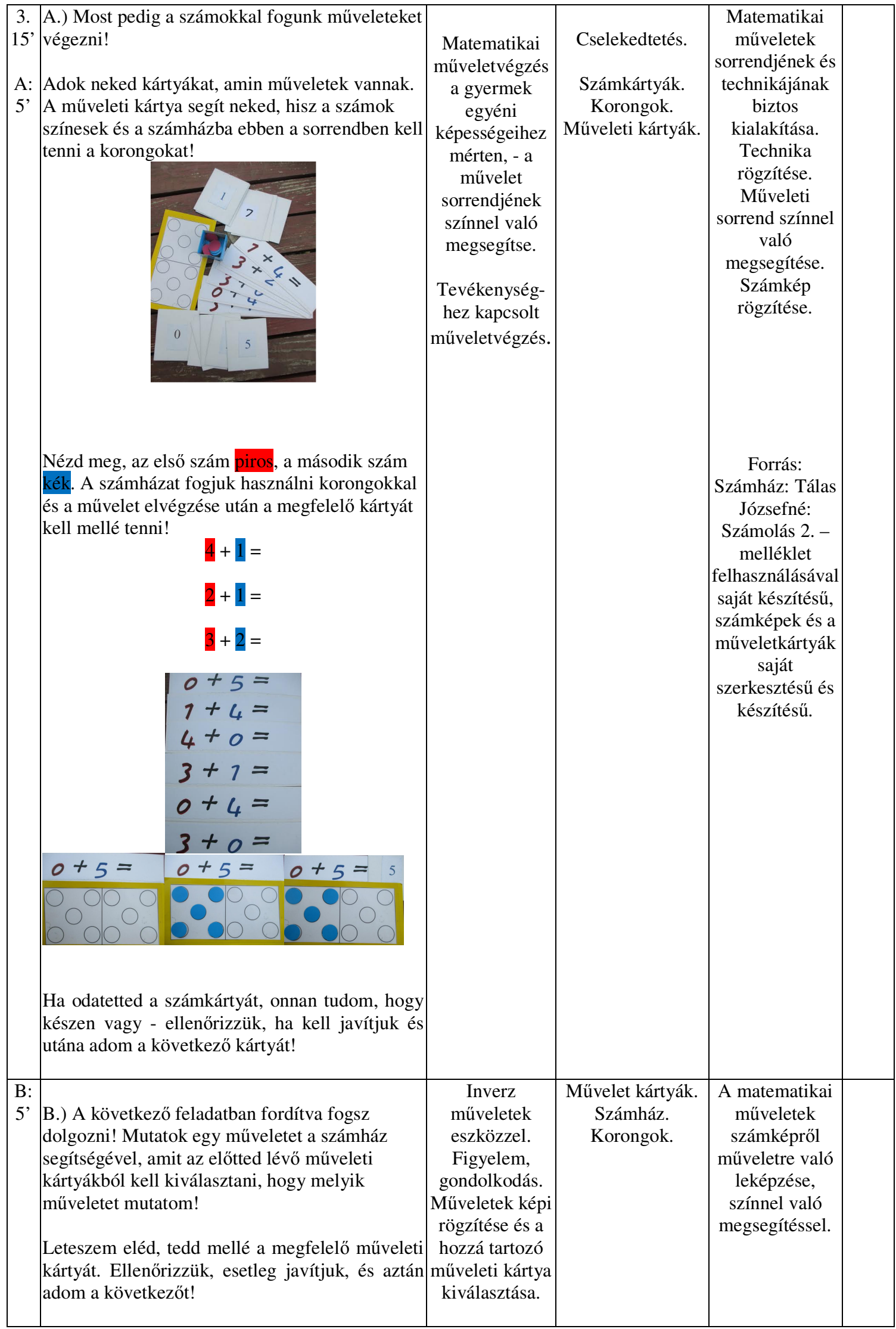




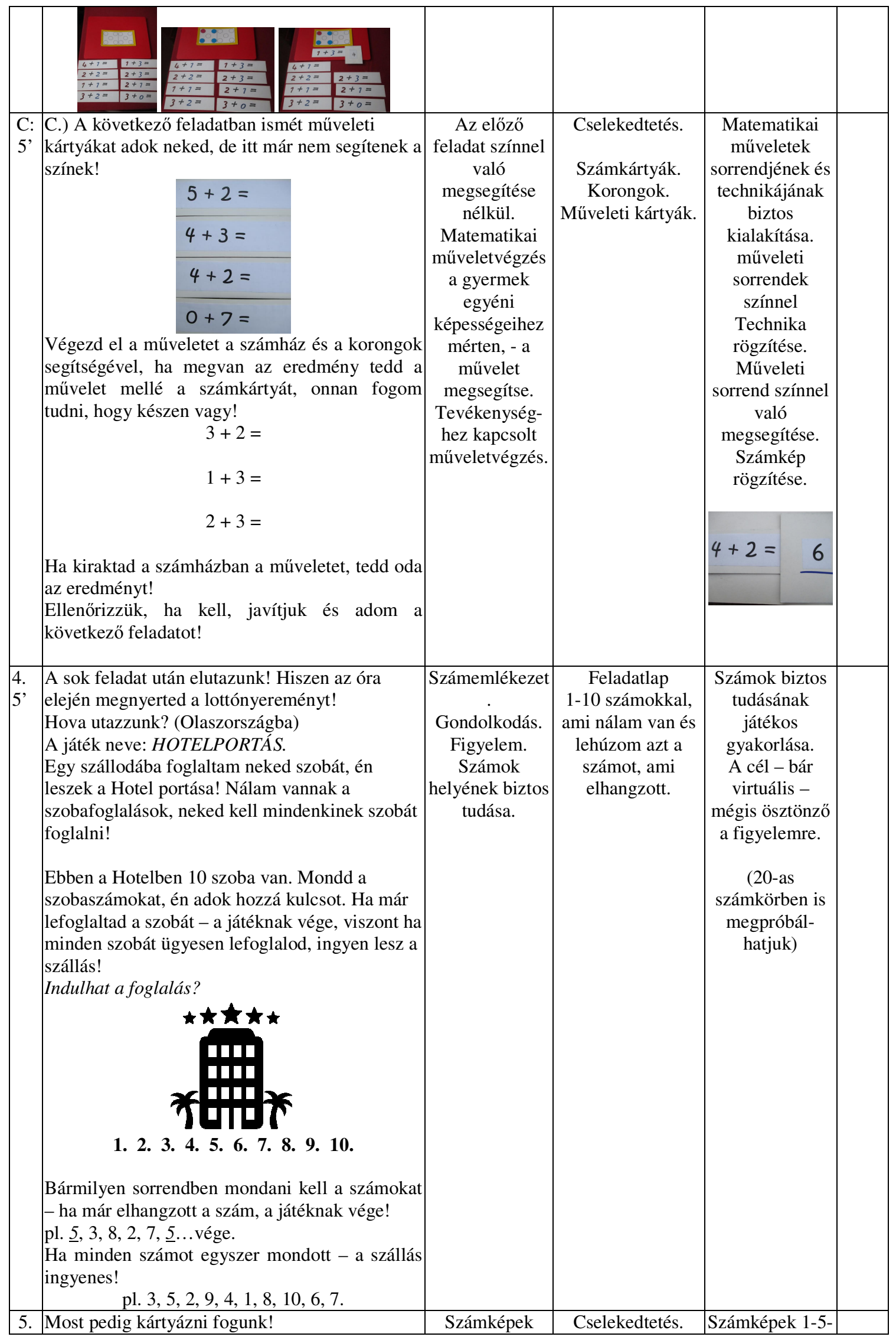




\begin{tabular}{|c|c|c|c|c|}
\hline 6 & $\begin{array}{l}\text { A játék neve: FLASH. } \\
\text { A játékszabály az, hogy adok neked } 3 \\
\text { kártyalapot, a többi lapot kettéosztva középre } \\
\text { teszem, ahogy fogy a lapod, innen lehet húzni, } \\
\text { mindig } 3 \text { lap lehet a kezedben. } \\
\text { Egy lapot leteszek, erre lehet rakni a kezedben } \\
\text { lévő lapokból úgy, hogy vagy színben, vagy } \\
\text { mennyiségnek vagy formának egyeznie kell. } \\
\text { Egyszer te raksz, ha van lap a kezedben ami jó, } \\
\text { aztán pedig én. } \\
\text { Az nyer, akinek hamarabb elfogynak a lapjai! }\end{array}$ & $\begin{array}{c}\text { játékos } \\
\text { gyakorlása. } \\
\text { Szín - forma - } \\
\text { mennyiség } \\
\text { egyeztetése 5- } \\
\text { ös számkörben. } \\
\text { Gyorsaság, } \\
\text { döntés } \\
\text { meghozatala. } \\
\text { Mennyiségek } \\
\text { többféle } \\
\text { formában való } \\
\text { megjelenítése, } \\
\text { számkép biztos } \\
\text { tudásának } \\
\text { játékos } \\
\text { gyakorlása. }\end{array}$ & Kártyalapok: & \begin{tabular}{|c} 
ig \\
többféleképpen \\
való \\
megjelenése. \\
Mennyiségállan \\
-dóság játékos \\
kialakítása. \\
Gyors \\
megfigyelés, \\
döntés. \\
Kártyalapok \\
forrása: \\
Saját \\
szerkesztésű, \\
készítésü, \\
laminált lapok.
\end{tabular} \\
\hline $\begin{array}{l}6 . \\
4\end{array}$ & $\begin{array}{l}\text { Befejezés: } \\
\text { Eszközök elpakolása. } \\
\text { Önértékelés, értékelés. } \\
\text { Melyik feladat tetszett a legjobban? } \\
\text { Melyik feladatban voltál szerinted a } \\
\text { legügyesebb? }\end{array}$ & $\begin{array}{l}\text { Önértékelés. } \\
\text { Emlékezet. } \\
\text { Ítéletalkotás. }\end{array}$ & Beszélgetés. & $\begin{array}{l}\text { Reális énkép } \\
\text { kialakítása. } \\
\text { Önbizalom } \\
\text { növelése. } \\
\text { Megbeszéljük, } \\
\text { melyik feladatot } \\
\text { kell még } \\
\text { gyakorolni. } \\
\text { Óra közbeni } \\
\text { folyamatos } \\
\text { ellenőrzés, } \\
\text { értékelés } \\
\text { mellett az óra } \\
\text { végén } \\
\text { összesítés és } \\
\text { egész órai } \\
\text { munka } \\
\text { értékelése. }\end{array}$ \\
\hline
\end{tabular}

